\title{
SGHWR: green to amber?
}

Allan Piper reports on uncertainties surrounding the next generation of British nuclear reactors.

Growing doubts about the future of the British-designed Steam Generating Heavy Water Reactor (SGHWR) have led the House of Commons Select Committee on Science and Technology to call an inquiry into progress on the reactor system, now at the end of the design stage. The committee two years ago successfully urged the controversial adoption of the SGHWR for the next phase of Britain's nuclear cnergy programme. It has now expressed concern over "the widely reported intention of the Secretary of State for Energy [Mr Anthony Wedgwood Benn] to review the SGHWR project in the near future".

In fact $\mathrm{Mr}$ Benn is currently awaiting reports on technical and economic aspects of the SGHWR from the United Kingdom Atomic Energy Authority (UKAEA), which has recommended a "take-stock" review, and from the Central Electricity Generating Board (CEGB). Parliamentary questions and statements from key leaders of management and unions within the nuclear industry have fed speculation that the reactor may be abandoned as part of the government's present review of public expenditure.

$\mathrm{Mr}$ Benn is expected to appear as an early witness in the select committee inquiry, probably before the forthcoming Parliamentary recess. The heads of the nuclear industries and the CEGB will be invited to appear at a later date.

Disagreement over the choice of the SGHWR as the commercial successor to the Advanced Gas Cooled Reactor (AGR) has continued since the initial $4000 \mathrm{MW}$ ordering programme was announced by $\mathrm{Mr}$ Benn's predecessor in July 1974. The go-ahead came then in spite of opposition within the nuclear industry and the CEGB's preference for a much larger programme using mostly American Pressurised Water Reactors (PWRs). The SGHWR was eventually favoured on safety grounds even though estimated construction costs were around $10 \%$ higher.

Officially, the SGHWR still has the green light. But there are amber tinges. The PWR has been given a clcan bill of health by the Chief Scientist at theDepartment of Energy (DEN), while technical difficulties have pushed design costs of the SGHWR above original expectations. Following a major design review in the middle of 1975 , and a further revision earlier this year, the CEGB has calculated that the SCHHWR could eventually prove more costly than equivalent coal-fired capacity.

This week Mr Benn spoke in Parliament of the new activity on the American reactor front. Last month he admitted that the UKAEA had recommended a careful look at progress on the SGHWR project, and hinted that once reports have been received the reactor's future will be considered in the light of recent changes on the energy scene. The CEGB, which currently has $15,000 \mathrm{MW}$ of new generating capacity either under construction or ready for commissioning, will probably indicate that with the present slump in elcctricity demand the first commercial SGHWR planned for Sizewell in Essex is no longer urgently required.

Ditching the project would mean the loss of political face and perhaps more, but it would also avoid economic and technological complications. Development of the SGHWR is not regarded as a crucial step along the path towards fast breeder reactor (FBR) tcchnology, while the export potential of the reactor remains limited; most other countries are expected to opt for the comparatively well proven PWR. Moreover, imported Canadian heavy water, needed to moderate the SGHWR, is likely to prove unexpectedly expensive.

Within the nuclear industry there is feeling that buoyancy can be maintained without the SGHWR if further commercial AGRs can be ordered. The first of the two AGR reactors at the $1,250 \mathrm{MW}$ installation at Hinkley Point in Somerset is now running successfully up to full power, bringing confidence that the much-publicised devclopmental hitches can now be left behind. Additionally, there are hopes that with a go-ahead for the first commercial FBR this autumn, fast breeder tcchnology could lag only three or four years behind SGHWR technology.

If the SGHWR is abandoned Britain could buy herself into PWR technology and establish an export base under licence. Japan and the USA, and several European countries, however, already have strong footholds in the market, which means that Britain would probably be restricted to the manufacture and export of component hardware. Mr Benn's junior, Alex Fadie, is meanwhile stressing that any reversal of SGHWR policy would not be at the expense of British technology.

Last week the DEN would only reaffirm that $\mathrm{Mr}$ Benn was awaiting reports from the UKAEA and CEGB. The UKAEA says simply that it is carrying out an appraisal which will be made available to $\mathrm{Mr}$ Benn in the near future. The CEGB is giving no outward sign that any imminent interruption to the SGHWR project is foreseen, and does not expect to have reliable cost figures ready for $\mathrm{Mr}$ Benn before next spring. An initial safety report is awaited from the Nuclear Power Company, responsible for design; this is not expected to arrive at the CEGB until next month, and is to be followed in turn by more detailed specifications in April 1977.

\section{Towards a conserver society}

Like other industrialised countries, Canada must look to conservation as an important element in its future energy stategy. This point has received considerable emphasis from an important quarter, as David Spurgeon reports from Ottawa

ENERGY conservation seems to be the major pre-occupation of the Science Council of Canada in its tenth anniversary year, judging by the statements and publications emanating from its members. The most recent came from the chairman, Josef Kates, who is president of a Toronto firm of systems analysts. "Energy conservation is not an option-it is a necessity," he says in the council's annual report. "... The highest priority in any comprehensive national energy policy should be $a$ wide-ranging, imaginative energy conservation effort. Such an cffort must involve every individual and every organisation, private or public."
Dr Kates reinforced his points at a press conference given when the report was published. The reason for his concern is that Canada is the "second most energy intensive country in the world, and energy shortages could threaten the very fabric of our way of life." He says that if Canada's energy requirements also double by 1990 , as is currently forecast, the needed capital investment could be as high as $\$ 200$ billion-or about 5 to $6 \%$ of GNP between then and now. This is some $50 \%$ higher than the $3.5 \%$ average between 1950 and 1975, and the interest rate on this capital is likely to bc 